\title{
Adatok a Kisalföld flórájának ismeretéhez III.
}

\author{
SCHMIDT Dávid \\ Nyugat-Magyarországi Egyetem Erdőmérnöki Kar, \\ Növénytani és Természetvédelmi Intézet, \\ 9400 Sopron, Bajcsy-Zsilinszky u. 4.; david.schmidt@emk.nyme.hu
}

Elfogadva: 2015. szeptember 30.

Kulcsszavak: élőhelyátalakulás, Győr, Kisalföld, ritka fajok, városi flóra

Összefoglalás: A dolgozat a Kisalföld határainkon belülre eső területén 2010-2015 közötti időszakban végzett florisztikai kutatások legfontosabb eredményeit ismerteti. A kutatási cél a Kisalföld északi része (elsősorban Győr és kb. 30 km-es vonzáskörzete) növényzetének részletes megismerése, érdekesebb florisztikai adatainak dokumentálása volt. Az adatok nagy része után értékelésre kerül azok jelentősége, növényföldrajzi, természetvédelmi szerepük. A felsorolás első része 3 mohafaj és 115 őshonos edényes növényfaj adatait tartalmazza, az Enumeráció második felében 23 adventív faj kerül közlésre. Az eredmények közül kiemelendő a Kisalföld területére nézve új Ornithogalum $\times$ degenianum és Rubus montanus, a természetvédelmi szempontból jelentős Cnidium dubium, Gentiana pneumonanthe, Samolus valerandi, Ophrys sphegodes újabb lelöhelyei, és a Kisalföldön igen ritka Dryopteris dilatata, Ophrys apifera, Ornithogalum refractum-ról közölt újabb adatok. A Szigetköz területén fontos felfedezés az Orobanche gracilis, Senecio doria és a Veronica teucrium egy-egy kis állománya. Az adventív elemek közül az országosan terjedő Cenchrus incertus, Rubus phoenicolasius most kerül közlésre elsőként a Kisalföldről, az Eleusine indica 1932 után került újra elő.

\section{Bevezetés}

A Kisalföld Magyarország területére eső északi és nyugati részéről megjelent flóraművek (WiERZBICKI 1824, EBENHöCH 1876, FEICHTINGER 1899, POlgÁr 1941), valamint összefoglaló tanulmányok (GÁYER 1916, ZólYOMI 1937) viszonylag hü képet adnak a táj 19-20. századi növényzeti viszonyairól, amelynek vázlatos ismertetése SimON (1962) munkájában található. Ezzel szemben, a növényzeti szempontból kevésbé változatos Dél-Kisalföld (Marcalmedence, Győri-medence déli része) florisztikai feltártsága ebben az időben még jelentősen elmaradt az északi résztől. A 20. század második felében, az intenzívvé váló mező- és erdőgazdálkodás, valamint az iparosítás hatására rendkívül felgyorsult az élőhely-átalakulás, azonban ebben az időszakban a botanikai kutatások jelentősen alábbhagytak. Az 1980-as és 90-es években föként Kevey sziget- 
közi dolgozatai lendítik fel újra a flóra és vegetáció feltárását (pl. KevEY 1998, Kevey és Czimber 1982, Kevey és Alexay 1994, 1996a, 1996b). A Szigetköz és Mosoni-sík flóráját más szerzők is kutatták (pl. Werner 1990, PINKe 1998), megjegyzendő azonban, hogy az adatok jelentős része a Szigetköz északnyugati feléből (Felső-Szigetköz) származik. Nagyobb változást az ezredforduló hozott, az új lendületet vevő, és a Kisalföld több tájegységére kiterjedő flórakutatást az utóbbi 15 évben megjelent számos floriszikai-növényföldrajzi dolgozat (pl. Pinke 2000, Pinke és Pál 2001, Barina 2003, Riezing 2005a, 2011, 2012a, 2012b, SCHMidt és BAUER 2005, SCHMIdt 2007, 2010, 2011, KirÁly et al. 2015) fémjelzik. A megjelent munkák - a nagyszámú florisztikai adat közlése mellett egyik legfontosabb eredménye a térséget ért nagymértékủ termőhely-átalakulás dokumentálása, a vegetáció aktuális állapotának bemutatása a régi adatok tükrében, valamint a megmaradt értékek számbavétele (pl. BARINA 2003, RIEZING 2012a, 2012b, SснмIDт 2007). Mindemellett megállapítható, hogy a munkák nagyobbik része továbbra is az északi tájegységek (Győri-medence: Rábaköz, de különösen a Szigetköz, Komárom-Esztergomi-sík: Györ-Tatai-teraszvidék) növényzetét tárgyalja. A Dél-Kisalföld (Marcal-medence, Kemenesalja) feltártságát LÁJER $(1997,1998)$ lápi vegetációtanulmányai javították, ugyaninnen KirÁLY és KirÁLY $(1999,2006)$ közölt néhány jelentős szórványadatot.

\section{Anyag és módszer}

A fő kutatási terület Győr és kb. 30 kilométeres vonzáskörzete, mely az alábbi kistájak területét foglalja magában (DövÉNYI 2010 alapján): Szigetköz (rövidítve az Enumerációban: SK), Mosoni-sík (MS), Csornai-sík (CS), PápaDevecseri-sík (PDS), Igmánd-Kisbéri-medence (IKM), Győr-Tatai-teraszvidék (GTT). Az Enumerációban a fajok az Új Magyar Füvészkönyv (Király 2009) sorszámai alapján szerepelnek, három részre osztva: az első részben a mohák (1 telepes májmoha és 2 lombosmoha), a második részben a honos (és archeofiton) növényfajok ( 8 haraszt, 73 kétszikủ és 34 egyszikü), a harmadik részben a neofitonok (19 kétszikü, 4 egyszikü) kerülnek felsorolásra. Az Enumerációban így összesen 141 fajról szerepelnek új adatok.

A lelőhelyek a következő módon kerülnek bemutatásra: kistáj (rövidítve), településhatár, településrész (ha van), földrajzi név, kvadrátazonosító (KIRÁLY és HoRVÁtr 2000 alapján). Ezen kívül indokolt esetben (természetvédelmi szempontból jelentős, védett fajok) további információk (populációméret, pontos tőszám, termőhelyleírás, természetvédelmi és növényföldrajzi vonatkozások, megtalálás éve) szerepelnek. Az előfordulások után a közreműködő adatközlők nevének monogramja olvasható. A cikk adatközlöi: $\mathrm{FL}=$ Füzfa Zoltán, $\mathrm{HL}=$ Hernádi László, $\mathrm{KG}=$ Király Gergely, PGy = Pinke Gyula, SzGy = Szabó 
György, SzT = Szuromi Tamás, WE = Werner Ervin. Amennyiben a lelőhelyet nem követi szerzői monogram, úgy az a szerző önálló florisztikai adata.

\section{Eredmények}

A 2010-2015 közötti időszakban a terepi kutatások elsősorban Győr és környékének még részleteiben nem feltárt részeire összpontosult (pl. a Csornai-sík keleti fele, Alsó-Szigetköz mentett oldali vizes élőhelyei), de jelentősebb számú új adat származik a Felső-Szigetközből, valamint a téti Sokoróaljáról (Pápa-Devecseri-sík) is. A Kisalföldre új őshonos taxonként került elő az Ornithogalum $\times$ degenianum, valamint a Rubus montanus, a meghonosodott adventívek közül a Cenchrus incertus, Rubus phoenicolasius. A Szigetköz területére nézve újként kimutatott taxonok között legjelentősebb a Senecio doria és a Veronica teucrium, amelyek egy-egy kis állománya csatornapartokon fennmaradt természetközeli mezsgyén él, valamint a Cnidium dubium, amelynek egyetlen állománya a győrladaméri Csikó-rétről került elő. A Győr-Tatai-teraszvidék homoki növényzetének kutatása is további új eredményeket hozott. A Kisalföld élőhelyi viszonyai között ritkának számító mohák és harasztok előfordulása vált ismertté a Szentiváni-erdőben (Leucobryum glaucum, Rhodobryum ontariense, Dryopteris dilatata, Athyrium filix-femina), kimutatásra került a Dipsacus pilosus, Geranium sibiricum, Rubus idaeus és Viola canina subsp. montana, megerösítést nyert az Achillea setacea és a Polycnemum majus homokpusztai előfordulása, új lelőhelyei kerültek elő a következő fajoknak: Helictotrichon adsurgens, Hypochaeris maculata, Ornithogalum refractum, Ulmus glabra, Viola ambigua. Kiemelendő a Győrszemere környékének nedves rétjein élöJuncus subnodulosus, Eriophorum angustifolium és Triglochin palustre egy-egy régi adatának megerősítése, továbbá Győr környéke belvizes élőhelyeinek időszakos megjelenésü ritkább taxonjai (Riccia cavernosa, Carex hordeistichos, C. secalina, Juncus sphaerocarpus, Samolus valerandi, Schoenoplectus supinus).

\section{Enumeráció}

$$
\text { Bryophyta }
$$

Riccia cavernosa Hoffm. emend. Raddi GTT: Győr: Hecsepuszta, homokos út kátyújában [8272/4]. IKM: Győr: Csanakfalu: Nagyrét [8371/4]; Gyirmót, a Határ utca és a 83. sz. foút között [8371/4]; Győrújbarát: Kisbarátfalu északi határán [8371/4]. SK: Ásványráró: Árvai-zárás, folyóparti iszapon [8171/3]. További adat a Kisalföld pereméről (Súri-Bakonyalja): Veszprémvarsány: a Romándra vezető út mellett [8572/4]. A faj élőhelyét (az ásványrárói és hecsepusztai adatot kivéve) olyan belvizes szántóföldek jelentik, amelyről a víz már visszavonult, de 
a talaj még vizes, iszapos. A 2013-as év kora nyári időszakában néhol tömegesen jelent meg a faj. Hazánkban veszélyeztetettség közeli, kevés recens adattal rendelkező (PAPP et al. 2010) májmoha. Polgár (1941) a hasonló $R$. crystallina L.-t említi belvizes helyekröl.

Leucobryum glaucum (Hedw.) Aongstr. GTT: Győr: Győrszentiván, Gazdákerdeje, telepített fenyvesben [8272/4], Szentiváni-erdő, telepített fenyvesben [8272/4]. PDS: Koroncó: Zöldmajortól D-re, homokra telepített erdeifenyvesben [8471/1]; Felpéc: Sísek-domb É-i része, nudum aljnövényzetü erdeifenyvesben [8471/3]. Minden felsorolt élőhelyén egyetlen, kb. tenyérnyi telepe került elő, tűlevélszőnyegen. Élőhelyein jellemző mohafaj a Dicranum scoparium, Scleropodium purum. Védett mohafaj, a győrszentiváni lelőhelytől 20 km-re keletre az ácsi Herkályi-erdőben Szücs (2007b) találta, ezenkívül csak peremhelyzetű előfordulásai ismertek a Kisalföldről (Dunaalmás, SzÜcs 2007a, valamint Kisbér, NÉMETH 2008).

Rhodobryum ontariense (Kindb.) Kindb. GTT: Győr: Győrszentiván, Szentiváni-erdő K-i része, homokra telepített feketefenyves felnyíló részén, tűavaron, kisebb telep [8272/3]. PDS: Felpéc: Sísek-domb, borókák között [8471/3]. Orbán és VAJda (1983) nem említi a Kisalföldröl.

\section{Cormophyta}

Honos fajok

8. Equisetum telmateia Ehrh. CS: Győr: Gyirmót, Széles-földek, mesterséges anyagnyerő gödrök alján és szélein, Equisetum arvense-vel vegyesen [8371/4]. A területen nem őshonos, megtelepedése feltehetően új keletű, behurcolás eredménye. Soó (1964-1980) szerint a Kisalföldön csak a Szigetközben él, PoLGÁR (1941) megyei flóraművében ugyanakkor nem szerepel.

15. Equisetum hyemale L. SK: Győr: Püspökerdő keleti felén kőrises ligeterdőben nagy $(100 \times)$ állomány, illetve a Mosoni-Duna pinnyédi oldalán az ártéri magas parton kisebb telep [mindkettő 8271/4].

16. Equisetum $\times$ moorei Newman CS: Győr: Bécsi úti nádas területén, régi anyagnyerő gödrökben és rekettyefüzesben, néhány $\mathrm{m}^{2}$-es telepek [8371/2].

18. Botrychium lunaria (L.) Sw. GTT: Győr: Győrszentiván: Ivánházapusztától É-ra, jó állapotú nyílt homokpusztagyepben, mintegy 60 tő [8272/4]. Ivánháza-puszta, illetve a vele szomszédos Gazdák-erdeje területéről ez a harmadik előfordulási adat, a korábban közölt lelőhelyek (SCHMIDT és BAUER 2005, SCHміDт 2011) a mostanitól mintegy 600 méter távolságban vannak északi, illetve nyugati irányban. Tapasztalataim szerint a növény rendszertelenül jelenik meg, évekig nem mutatkozik. A fenti lelőhely 2012-es megtalálása után 2013ban és 2014-ben egyetlen példányt sem sikerült megfigyelni, és a másik két lelőhelyen is eltűnt vagy lappang a növény. 
42. Athyrium filix-femina (L.) Roth GTT: Győr: Győrszentiván: Szentivánierdő [8272/3]. Régebbi erdőtűz nyomán összedőlt telepített fenyvesben egyetlen példány került elö, Dryopteris filix-mas, $D$. dilatata és $D$. carthusiana példányai között. Ugyanitt jellemző mohafaj a Dicranum scoparium, elöfordul a Lophocolea heterophylla. A fenyvest 2013-ban levágták, az élőhely megsemmisült. PDS: Tét: Tétszentkúttól ÉNy-ra lévő erdeifenyvesben, 3 tő (KG-SD) [8570/2]. Soó (1964-1980) szerint a Kisalföldön csak a Hanságban fordul elö.

51. Polystichum aculeatum (L.) Roth PDS: Tét: Tétszentkúttól ÉNy-ra lévő erdeifenyvesben, 3 tő (KG-SD) [8570/2]. A Kisalföldön igen ritka, legutóbbi kisalföldi adatát RIEZING (2005b) ismertette.

56. Dryopteris carthusiana (Vill.) H. P. Fuchs GTT: Györ: Győrszentiván, Erdőteleptől D-re, telepített fenyvesben 2 tő [8272/4]; Győrszentiván-Kertváros: a 10-es főúttól É-ra lévő telepített erdeifenyvesben, szálanként [8272/3]. PDS: Felpéc: Sísek-domb [8471/3]; Koroncó: Zöldmajor és a Marcal között, telepített erdeifenyvesben, néhány tő [8471/1]; Mórichida: Tördemészpuszta, erdeifenyvesben (KG-SD) [8570/2]; Tét: Tétszentkúttól ÉNy-ra lévő erdeifenyvesben, több tucat tő (KG-SD) [8570/2].

57. Dryopteris dilatata (Hoffm.) A. Gray GTT: Györ: Győrszentiván: Szentiváni-erdő [8272/4]. Régi leégés nyomán összedőlt telepített fenyvesben egyetlen példány került elő 2012-ben (az Athyrium lelőhelyén). A fenyvest 2013ban levágták, az élőhely megsemmisült. A páfrány WeRner (1990) nyomán ismert a területről, aki a "Győrszentiván körüli erdőkben” találta. PDS: Tét: Tétszentkúttól ÉNy-ra lévő erdeifenyvesben, 1 tő (KG-SD) [8570/2].

100. Salix elaeagnos Scop. SK: Dunakiliti: a Duzzasztómü környékének mesterségesen feltöltött nyers kavicsfelszínein felverödött cserjésekben jellemző elegyfa (különösen a Fazekas-zátonyon) [8069/2; 8069/4]; Rajka: a Tározótér területének kavicsfelszínein, továbbá a Szigeti-Duna és az ÖregDuna part menti nyers hordalékán, magaspartjain helyenként állományképző [7969/3; 7969/4; 8069/2]. Dunakiliti lelőhelyéről KIRÁLY és KIrÁLY (2009) is közli előfordulását.

133. Ulmus glabra Huds. GTT: Győr: Győrszentiván, Szentiváni-erdő É-i részén, telepített fenyvesben, 1 kisebb fa [8272/3]. PolgÁr (1941) flóraműve csak a Pannonhalmi-dombságról jelzi, újabban RIEzıng (2005a) közölte elöfordulását két Duna menti ligeterdőből. Az új termőhelyek nem ártéri környezetben, hanem száraz homokon álló faültetvényben vannak. PDS: Marcaltö: a községi temető melletti keményfás ligeterdőben (KG-SD) [8570/3].

152. Thesium dollineri Murb. GTT: Győr: Győrszentiván-Ivánháza, Gazdák-erdeje, homoki parlagon néhány tő [8272/3]. Polgár (1941) szerint Győr megyében ritka, négy lelőhelyét adja meg, közülük a „Gönyűi-töltés” az új előfordulás közelében található. 
155. Loranthus europaeus Jacq. GTT: Győr: Győrszentiván, Gazdák-erdeje, az egykori erdősztyep-tölgyes idős kocsányos tölgyein [8272/4]. CS: Győr: Belváros, a Radó-sziget D-i csücskén álló vörös tölgyön él néhány példánya [8371/2]. Általában magányos tölgyeken vagy ritkás facsoportokban fordul elö, zárt tölgyesekből (pl. Győr: Püspökerdő, Kunsziget: Tátai-erdő, Vének: Somoserdő) hiányzik. További környékbeli adatai Abda és Vámosszabadi mellől ismertek (SCHMidt és BAUer 2005).

206. Polycnemum majus A. Braun CS: Győr: Gyirmót, Széles-földek, építési terület nyílt felszínén, 1 tő [8371/4]. GTT: Győr: Likócs, a Segítőház mögötti felhagyott üzemanyagtelep területén, nyílt homoki gyomtársulásokban, néhány tucat egyed [8272/3]. Polgár (1941) Győr megye homokvidékeiről gyakori fajként említi, ennél ma jóval ritkább, aktuális termőhelye csak a fenti két pontról ismert.

223. Chenopodium murale L. CS: Győr: Újváros, a Kossuth Lajos és Bálint Mihály utcán és a Bercsényi ligetben, falak tövén, több helyen [8371/2]. SK: Győrzámoly, a falu É-i részén, előkertben [8271/3]. A Kisalföldön települési környezethez kötődő gyomnövény, korábbi győri termőhelyei (SCHMIDT 2010) részben megszüntek.

313. Moenchia mantica (L.) Bartl. CS: Rábapatona: a Rába jobb parti töltésén a győri településhatár felé, a Haraszti-rét mellett egy nagyobb folton tömeges. [8371/3]. Néhány példány Győr területén is található. Győr megyében PoLGÁR (1941) szintén a Rába mellett, réteken találta, KiRÁLY et al. (2015) számos lelőhelyét adja meg a Rába mellől (Sobortól DK-re). Jelenleg ismert északi és keleti elterjedési határa a Kisalföldön Rábapatonánál található, amely jól tükrözi a faj kissé mészkerülő jellegét.

323. Scleranthus annuus L. PDS: Felpéc: Hegyaljai-dűlő, homokos dülőúton, kevés példány [8471/4]. Tápanyagszegény talajokon országszerte gyakori gyomnövény, Polgár (1941) is közönséges növényként említi. Mindezek ellenére az utóbbi 15 évben csak a most említett lelőhelyen sikerült megfigyelni Győr tágabb környékén, adata ezért kerül közlésre.

346. Silene dichotoma Ehrh. CS: Győr, a vasúti Rába-hídnál, kőzúzalékon [8371/2]. Lokális adventívként a 2011. és 2012. években bukkant fel, azután eltűnt.

353. Silene nutans L. GTT: Győr: Győrszentiván, Haraszt-erdő, több ponton [8272/3], Hecsei-erdő [8272/3]. Ipari nagyberuházás miatt a Hecsei-erdőt 2011-ben kivágták, a területen élő növényfajok elpusztultak. Ezek közül a legjelentősebbek: Dianthus serotinus, Ophrys apifera, Orchis militaris, Oxytropis pilosa, Taraxacum serotinum, Teucrium montanum.

423. Clematis recta L. SK: Győr: Bácsa: Mosoni-Duna töltésgyepjében több helyen [8272/3]; Kisbajcs: Szavai-csatorna szegélyében [8272/3]; Püski: Duna töltésgyepjében néhány tő [8170/2]. CS: Gyirmót: Rába-töltés [8371/3]. 
426. Adonis flammea Jacq. GTT: Győr: Győrszentiván, Ivánháza és az Erdeitanya között, kivágott fenyves helyén kialakult egyéves homoki gyomtársulásban, néhány tő [8272/4]. Ritkán szem elé kerülő faj, további adatait SCHMIDT és BAUER (2005) sorolja fel.

428. Ranunculus circinatus Sibth. CS: Győr: Gyirmóti szivattyútelep közelében a Marcal-közi csatornában [8371/3]. SK: Győr: Sáráspuszta, a Dunalaposér északi részében, kb. 150 méteres szakaszon [8271/4].

437. Ranunculus illyricus L. PDS: Mórichida: Ferencházapuszta környékén mezsgyéken, akácosok szélén (KG-SD) [8470/4], Mórichida: Tördemészpuszta, mezsgyéken (KG-SD) [8570/2]; Csikvánd: a falutól Ny-ra, az országút mellett egy kis szárazgyep-töredékben (KG-SD) [8570/2]. Koroncó: Zöldmajor, fenyvesek közötti zárványgyepekben [8471/1]. A Győr környéki Kisalföldön nem ritka, vegetáló (nem virágzó) telepei gyakran bukkannak fel kisebb homoki gyeptöredékekben, mezsgyéken, akácosok szélén. Korábbi adatait SCHMIDT és BAUER (2005), SCHMIDT (2010), RIEZING (2012a) ismerteti.

448. Ranunculus arvensis L. IKM: Győr: Malomszéki-dűlő, belvizes szántó szélén, egyetlen példány [8371/4]. A POLGÁR (1941) szerint még közönséges szántóföldi növénynek az elmúlt 15 év alatt ez az egyetlen megfigyelése Győr környékén.

465. Thalictrum flavum L. SK: Vámosszabadi: Öreg-Duna ártere [8171/4]; Győr: Likócstól K-re a Mosoni-Duna árterén, nádas szegélyén [8272/3]. Ártéri magaskórósok, nádasok szegélyének növénye, termőhelyeinek degradálódása következtében ritkulóban van.

477. Papaver argemone L. SK: Vámosszabadi: Bodzás, az épülő Szitásdomb lakópark területén, nyílt homoki gyomtársulásokban [8271/4]. Tápanyagszegény talajokat kedvelő növény, emiatt a térségben ritka, PoLGÁr (1941) egy-egy adatát közli Öttevény és Mórichida mellől. A Szigetközből nem volt adata.

485. Corydalis cava L. GTT: Győr: Győrszentiván, Erdeitanyától Ny-ra, rossz állapotú telepített fenyvesben, kb. 25 tőből álló telep [8272/4]. Élőhelyén tömeges a Mahonia aquifolium. A Kisalföld keleti részén ritka, újabb adatát RIEZING $(2011,2012 a)$ közli a Bőnyi-erdőből, ahol KEVEY (2015) is találta.

496. Sisymbrium strictissimum L. GTT: Győr: Győrszentiván, a Gazdákerdeje telepített homoki fenyveseiben és akácosaiban, nyílt talajfelszíneken, szórványosan [8272/4]; Gönyü: Gönyűi-erdő, hasonló élőhelyeken, helyenként nagy egyedszámban [8272/4]. Soó (1964-1980) üde és nedves talajokat kedvelő ligeterdei elemként mutatja be. Újabban homokra telepített erdők (fenyvesek, akácosok) nyílt talajfelszínnel rendelkező, kifejezetten száraz, árnyékos részein szembetűnő terjedése figyelhető meg a Kisalföldön. Első ilyen jellegű megfigyeléseit SCHMIDT és BAUER (2005) közölte.

504. Myagrum perfoliatum L. PDS: Győrszemere: Bot-teleki-dűlő, mákföldön 2 példány [8471/3], Hatos-dűlő, parlagon néhány szál (SD-KG-PGy-WE) 
[8471/2]. Polgár (1941) szerint Győr megyében ritka, néhány adata közül az egyik győrszemerei. Újabb jelzései nem voltak a Kisalföldről.

505. Isatis tinctoria L. MS: Hegyeshalom: Modrovics-földek, vasút menti mezsgyéken [8069/1]. SK: Dunakiliti: duzzasztómü környékén és a Fazekaszátonyon [8069/2], Dunasziget: Duna-parti kavicsos út mellett az 1833. folyamkm.-nél, szikár, gyomos gyeptársulásban [8070/3]. A Duna-parti kavicsfövenyről már SCHMIDT és BAUER (2005) is jelezte előfordulását.

532. Cardamine impatiens L. GTT: Győr: Győrszentiván, a Gazdák-erdeje homokra telepített fenyveseiben és akácosaiban, nyílt talajfelszíneken, szórványosan [8272/4], Gönyü: Gönyüi-erdő erdeiben, hasonló élőhelyeken [8272/4]. A Sisymbrium strictissimum-hoz hasonló körülmények között, homoki erdőkben jelenik meg, spontán betelepülőként. PolgáR (1941) még nem említi a homokvidékről.

539. Cardamine hirsuta L. GTT: Győr: a Nádorvárosi köztemetőben, laza talajú, üde, árnyas gyomtársulásokban, több ponton, kevés példány [8371/2]. Polgár (1941) csak a Pannonhalmi-dombságról jelzi. A Kisalföldön ritka gyomnövény, aktuális adatai nem voltak.

545. Cardaminopsis arenosa (L.) Hayek SK: Győr: Tordai-sziget, puhafás ligeterdőben, árvízjárta nyílt iszapos felszínen, 1 példány [8272/4]. PoLGÁR (1941) flóraművének élőhelyre utaló megjegyzése („friss homokon a Duna szigetein") hasonló előfordulási körülményekre utal.

645. Saxifraga bulbifera L. CS: Győr: a Rába jobb parti töltésgyepjében Gyirmót közelében, több ponton [8371/3]. PolgÁR (1941) szerint mindenütt gyakori növény, az utóbbi 15 évben azonban csak a fenti lelőhelyek ismertek. Kissé mészmentes talajú gyepekben a Marcal-medencében (és a Nyugat-Dunántúlon) már gyakorivá válik.

670. Rubus idaeus L. GTT: Győr: Győrszentiván: Szentiváni-erdő [8272/3]. Régebbi erdőtűz nyomán részben összedőlt, homokra telepített feketefenyvesben került elő, fatörzsek között, üde termőhelyen. Szubspontán előfordulás (erdészeti szaporítóanyaggal történt vagy madarak általi behurcolás), a Kisalföld belső részein nem őshonos, korábbi adatai nincsenek.

---. Rubus montanus Lib. ex Lej. SK: Dunakiliti: a Görgetegi-Duna-ág torkolata közelében, az Öreg-Duna partjával párhuzamosan futó kavicsos út mellett, üde szegélycserjésben, egy telep [8070/1].

814. Crataegus laevigata (Poir.) DC. CS: Győr: Gyirmót, Horgászfalu, a Holt-Rába mellett szegélycserjésekben néhány bokor [8371/3], Gyirmót, a Marcal és a Rába összefolyásánál, kocsányos tölgyes ligeterdőben (SD-KG) [8371/3]. Gyirmótról EBENHöCH (1876) közölte elsőként, PoLGÁR (1941) saját kisalföldi adatot nem említ.

866. Astragalus exscapus L. GTT: Győr: Győrszentiván: Szentiváni-erdő Ny-i részén, idősebb telepített fenyvesek közötti zárványgyepekben szórványosan van 
jelen, továbbá a Szentiváni-erdő K-i felének legnagyobb sztyepprétjén, domboldalban él legalább 100 töves állománya [mindkettő 8272/3]. A homokpusztán összességében erős állományai élnek még, további adatait SCHMIDT és BAUER (2005), Schmidt (2010) és Riezing (2012a) sorolja fel.

922. Lathyrus latifolius L. IKM: Győr: Ménfőcsanak-felső vasúti megállóhely közelében, vasúti mezsgyén, néhány tő [8371/4]. A Kisalföldről (Szákszend) RIEZING (2012a) említi első ízben.

921. Lathyrus sylvestris L. SK: Kunsziget: a Mosoni-Duna jobb parti töltésén, a Győrzámollyal szemben lévő szakaszon, egy közepes méretü telep [8271/3]. GÁYER (1916), valamint RIEZING (2005) a Duna alsóbb szakasza mellől (Komárom, Neszmély) kaszálórétekről jelzi, a Szigetközből nem volt adata.

1013. Geranium lucidum L. GTT: Győr: Győrszentiván: Szentiváni-erdő északi felén, telepített fenyvesekben [8272/3]. PDS: Koroncó: Zöldmajor és Pókvár között, telepített fenyvesekben és akácosokban, helyenként tömeges [8471/1]. Bolygatott erdőkben, szegélyeken terjedőben lévő honos taxon, mely az Alföldön föként fenyves és akácos állományokban jelenik meg. A Kisalföldröl elsőként Schmidt és BAUer (2005) jelezte, majd Király et al. (2009) a PápaDevecseri-síkról, RIEzıng (2012a) a Bőnyi-erdőből közölte.

1063. Euphorbia lucida Waldst. et Kit. SK: Győr: Bácsa: a Mosoni-Duna jobb parti töltésének lábánál, szórványosan [8271/4, 8272/3]. Kisalföldi elterjedési területe Győr környékére szorítkozik, ahol ártéri gyepmaradványokban bukkannak fel állományai, de visszaszorulóban van.

1083. Acer tataricum L. IKM: Győr: Kismegyer: Agrokerrel szembeni löszgyeptöredék szélén, ültetett egyed, a gyepben spontán kelt magoncok [8371/4]. A Kisalföld területén csak a Szigetköz ligeterdeiből ismertek őshonosnak tekintett állományai (Kevey és AleXAY 1992, Király és Király 1999).

1089. Impatiens noli-tangere L. SK: Győr: Pinnyéd, a Mosoni-Duna árterén a Szúnyog-szigetnél, néhány példány [8271/4]. A Felső-Szigetköz ligeterdeiben még nem ritka növény, az Alsó-Szigetközben már kuriózumnak számít, más elöfordulásáról jelenleg nincs adat.

1142. Hypericum tetrapterum Fr. SK: Lipót: Morotvató melletti mocsárréten, elszórtan [8170/2]. Polgár (1941) még az Alsó-Szigetközben gyakorinak tartja, a nedves rétek megszünése és eljellegtelenedése miatt azonban az egész Kisalföldön megritkult.

1159. Viola ambigua Waldst. et Kit. GTT: Győr: Győrszentiván: Szentivánierdő nyugati részén, homoki gyepben [8272/3]. Idősebb telepített fenyves ritkás, gyepesedő foltján egy ponton került elö tucatnyi példány, Astragalus exscapus, Viola rupestris, Polygala comosa, Helictotrichon pubescens társaságában. PolgáR (1941) a szintén győrszentiváni Haraszt-erdőből említi. 
1161. Viola reichenbachiana Jord. SK: Győr: Püspökerdő, kőrises ligeterdőben, több m²-es folton [8271/4]. Az Alsó-Szigetközből ZóLyOMI (1937) nyomán ismert (Tátai-erdő), újabb adata nem volt.

1164/2. Viola canina L. subsp. montana (L.) Hartm. GTT: Győr: Győrszentiván: Szentiváni-erdő ÉNy-i részén, homokra telepített erdeifenyves és cseres alatt, néhány tucatnyi tő (2012) [8272/3]. Élőhelyének döntő része 2013-2014ben a fenyves kivágása következtében megszűnt. Korábban csak a dombvidékről közölték (PolgÁr 1941).

1217. Chamaenerion angustifolium (L.) Scop. CS: Győr: Újváros, a lebontott Kekszgyár helyén (2013), törmeléken, 2 tő, lokális adventív [8371/2].

1218. Chamaenerion dodonaei (Vill.) Holub SK: Dunasziget: Duna-parti kavicsos út mellett [8069/3]; Ásványráró: Árvai-zárásnál és az Árvai-szigeten, a part menti út kavicsdepóniáin [8171/3]; Dunakiliti: a Duzzasztómű környékének mesterségesen feltöltött területén, nyers kavicsfelszíneken (Fazekas-zátony) [8069/2; 8069/4]; Lipót: Duna-parti kavicsos út mentén sokfelé [8170/2]; Rajka: a Tározótér terméskövekkel rakott gátján, végig gyakori [7969/3; 8069/1; 8069/2]. Lipótról már Polgár (1941) említi, majd Werner (1990), KeveY és AleXAY (1992) közöl újabb adatokat. BALOGH (2003) Lipót melletti kavicsfeltöltéseken egyenesen helyi inváziójáról számol be.

1241. Sanicula europaea L. SK: Győr: Püspökerdő, kavicsos erdei út mellett 2 tő [8271/4]. Előfordulási körülményei behurcolásra utalnak, erősíti a feltételezést, hogy korábban nem volt környékbeli adata.

1260. Pimpinella major (L.) Huds. SK: Győr: Tordai-sziget, puhafás ligeterdőben [8272/4]; Győrladamér: Fekete-dűlő és Patkányos között üde gyepekben $[8271 / 2]$. Az Alföld egész területén csak a montán elemekben gazdag FelsőSzigetköz ártéri ligeterdeiben elterjedtebb, másutt (így a Kisalföld más tájegységein is) igen ritka vagy hiányzik.

1262. Aegopodium podagraria L. SK: Győr: Tordai-sziget, idős fehér füzes ligeterdőben, kisebb telep [8272/4]. Győr területén az egyetlen előfordulás. A Szigetköz ártéri ligeteiben sokfelé tömeges, mely Vénektől keleti irányban (részben az elkeskenyedő hullámtér és az erdők hiánya okán) szinte eltűnik, Gönyü és Neszmély között RIEzıNG (2005) csak Komárom: Szent-Pál szigeten találta.

1287. Bupleurum tenuissimum L. CS: Győr: a Rába töltésgyepjében a Marcal torkolata közelében, néhány tő [8371/3]. A Rába mellől már PoLGÁR (1941) jelezte, újabb adatai csak a Győrtől DK-re lévő szikesekről voltak (SCHMIDT 2007), másutt a Kisalföldön csak a Fertő mentén él.

1301. Cnidium dubium (Schkuhr) Thell. SK: Győrladamér: Fekete-dülő (Csikórét), a mocsárrét legjobb természetességủ foltjain, néhány tucat tő [8271/2]. A Rábaköz jó állapotú mocsárrétjein még elterjedt (adatait SCHMIDT 2010 öszszegzi), a Szigetközben másutt nem került elő. RIEZING (2012a) egy újabb ada- 
tát hozza a Dunától távolabb (Nagyigmánd), KIRÁLY et al. (2015) a Hanság és a Rábaköz több pontjáról jelzi.

1352. Hottonia palustris L. SK: Győr: Sáráspuszta, a Dunalapos-ér északi részében, kb. 150 méteres szakaszon [8271/4]. CS: Kóny: Barbacsi-csatornában [8370/3]. A Kisalföld területén a Hanságban ma sem ritka (Király G. ex litt.), másutt erősen visszaszorult, így Győr környékén is, ahol korábban sokfelé (így az Alsó-Szigetközi csatornákban, sőt Nagyszentjános mellett is) előfordult.

1363. Samolus valerandi L. CS: Győr: Gyirmót, Széles-földek, építési terület nyílt nedves felszínein tömeges [8371/4]. A közelben több élőhelye is ismert (SCHMIDT 2010), melyeken kedvező csapadékviszonyok esetén rendszeresen (sokszor tömegesen) megjelenik. PDS: Koroncó: Zöldmajortól Ny-ra, anyagnyerő gödrökben [8471/1]. Országosan ritka faj, elterjedési centruma a Balaton térségében és a Kisalföld egyes körzeteiben található.

1385. Gentiana pneumonanthe L. SK: Ásványráró: Szárcsás-tó, mocsárréttöredéken [8171/3]; Bagamér, kubikgödrökben kialakult nedves, kavicsos felszíneken, pionír cserjés között [8171/3]; Dunaszeg: Remisz-dűlő K-i részén, közel a töltéshez, kékperjés gyepfolton, több példány [8171/3]; Győrladamér: Feketedűlő (Csikó-rét), mocsárréten, több ponton [8271/2]; Nagybajcs: Vörös-rét, jó állapotú mocsárréten [8271/2].

1495. Galeopsisbifida Boenn.SK: Ásványráró: Új-sziget, nemes nyárasokban, utak mentén elég gyakori [8171/1, 8171/3]. Adathiányos faj, amelyben közrejátszik a rokon Galeopsis fajokkal, elsősorban a hasonló élőhelyigényü G. tetrahit L.-tel való téveszthetősége, valamint a nemzetségen belüli hibridizációs hajlam is. A Szigetköz megfelelő élőhelyein valószínűleg általánosan megtalálható.

1581. Solanum villosum Mill. CS: Győr: Belváros, Rába kettős híd, útszéli gyomtársulásban, néhány egyed [8371/2]. Polgár (1941) a közel rokon $S$. alatum Moench-ről közöl kisalföldi adatokat. A S. villosum s. l. alakkör a bogyók színéről könnyen felismerhető csoport, ennek ellenére az ország területéről alig van recens adata, amelynek a valódi visszaszorulás mellett élőhelyeinek alultérképezettsége is oka lehet.

1602. Verbascum thapsus L. SK: Rajka: a Tározótér É-i részén, a Jónási-tavak környékén, többfelé [7969/3]. A Kisalföldnek csak az északnyugati részéröl vannak adatok (Hanság, Mosoni-sík, Felső-Szigetköz), másutt hiányzik.

1629. Pseudolysimachion orchideum (Crantz) Wraber CS: Győr: Rába bal parti mezofil töltésgyepjében az ikrényi határ közelében [8371/3], hasonló élőhelyen az M1-es autópálya Rába-hídja mellett [8371/2]. SCHмIDT (2010) a töltés rábapatonai szakaszáról ismertette, Király (ex litt.) a Kapuvári-sík több pontján találta.

1639. Veronica teucrium L. SK: Lipót, a morotvató partján, természetközeli mezsgyén [8170/2]. A Kisalföldön csak Komárom-Esztergom megyéből jelzi Soó (1964-1980). Új a Szigetközre. 
1645. Veronica verna L. PDS: Mórichida: Tördemészpuszta, gabonavetésben, savanyú homokon (KG-SD) [8570/2]. Élőhelyi igényeinek a Kisalföldön csak a Mórichida-Csikvánd környéki mésztelen homoktalajok felelnek meg, ahol több más hasonló karakterü fajjal él együtt.

1661. Melampyrum arvense L. GTT: Győrszentiván: Gazdák-erdeje Ny-i peremén, homokbucka nyílt felszínén néhány tő (időszakos megtelepedés) [8272/4]. Már a múlt század első felében is ritka volt, PolgáR (1941) két lelőhelyadatának egyike az újonnan megtalált hely közelében található („Ivánháza in silva”).

1695. Orobanche reticulata Wallr. CS: Rábapatona: Vasút-alatti-dülö, gabonatábla szélén egy példány, Cirsium arvense-n [8371/1]. Soó (1964-1980) szerint a Kisalföldön szórványos, aktuális adatai azonban csak Mosonmagyaróvár környékéről vannak (Werner ex verb.). Új a Rábaköz flórájára.

1700. Orobanche gracilis Sm. SK: Kisbajcs: Mosoni-Duna töltésének lábánál, Lotus corniculatus-on, legalább száz tő [8272/3]; Győr-Bácsa községhatárban is, két tő [8272/3]; Dunasziget: Cikolasziget, a Duna töltésgyepjében szórványosan [8070/3]. Eddigi egyetlen szigetközi adata 1903-ból, a püspökerdei Tákóból származik (PolgÁr 1941). Másutt a Kisalföldön nem él.

1701. Orobanche caryophyllaea Sm. CS: Győr: Gyirmót: az É-D-i gátút tövében, mezofil gyepben, néhány csoport, Galium verum-on [8371/3]. A 2000-es évek közepe óta ismert állomány, első megtalálója Peimli Piroska. A Kisalföldön Soó (1964-1980) szerint szórványos, de csak két régi megfigyelése volt: EBENHöch (1876): Koroncó és PolgÁR (1941): Ács.

1703. Orobanche lutea Baumg. GTT: Gönyü: Gönyüi-erdő, tisztáson egy csoport (2014) [8272/4]. PolgÁR (1941) a kisalföldi területen is gyakorinak tartja, jelenleg a homokpuszta területéről máshonnan nem ismert aktuális adata. A Schmidt (2010) által ismertetett Écs: Petkevár-i adat a Pannonhalmi-dombság egyik északi, lepusztult elővonulatának tekinthető (de már Igmánd-Kisbérimedence, Kisalföld).

1726. Galium odoratum (L.) Scop. GTT: Győr: Győrszentiván: Szentivánierdő É-i része (az M19-es úttól északra) [8272/3]. Vegyes összetételü (fenyő-domináns) telepített erdőben él néhány szobányi területen. A Kisalföld keleti felében igen ritka, RıEZING (2011) a Bőnyi-erdőből jelzi.

1785. Dipsacus pilosus L. GTT: Győr: Győrszentiván, Gazdák-erdeje, galagonyával spontán becserjésedett állomány nyílt felszínein, számos egyed [8272/4]. SK: Ásványráró: Alsó-Új-sziget, ártéri puhafaliget nyílt talajfelszínnel rendelkező, nyirkos, bolygatott részén [8171/1]. A Kisalföld (különösen annak keleti, szárazabb felében) ritka, PolgÁr (1941) csak a Rába mellől (Ómalomsok) jelzi.

1796. Scabiosa triandra L. SK: Ásványráró: Kucsérok D-i része, száraz gyepben [8171/3]; Győr: Tordai-sziget, kavicsos úton [8272/4]; Győrladamér: Feketedűlő (Csikórét), néhány szál, cserjésedő legelőn [8271/2]; Lipót: a gátőrháztól D-re, 
mezsgyén [8170/4]; Rajka: a Tározótér töltésén sokfelé [7969/3]. Vörös Listás, adathiányos faj (KIRÁLY 2007), elterjedésének súlypontja a Szigetközben van. Itteni élőhelyeit zavart, szárazodó jellegű, kavicsos talajú gyeptársulások jelentik.

1860. Pulicaria vulgaris Gaertn. CS: Rábapatona: a közúti Rába-híd mellett, keréknyom taposott gyepjében, tucatnyi tő [8370/4]. PoLGÁR (1941) közönségesnek tartja, de újabban rendkívül megritkult, a környékről ez az egyetlen aktuális adata.

1862. Carpesium cernuum L. SK: Mosonmagyaróvár: Lóvári-erdő, keményfás ligeterdőben [8069/4]. A Kisalföldön ritka, régi jelzései is csak a FelsőSzigetközből vannak.

1903. Achillea setacea Waldst. et Kit. GTT: Győr: Likócs, a hecsei felüljárótól ÉNy-ra Carex humilis-es homokpusztagyepben [8272/3], Hecsepuszta északi része, nyílt homokpusztagyepben, Achillea pannonica-val együtt, kis egyedszámban [8272/3]; Nagyszentjános: M1-es autópálya gönyüi lehajtójától É-ra lévő homokbuckákon (a megyehatáron), néhány sarjtelep [8373/1]. PoLGÁR (1941) szerint a homokon szórványos, újabb megfigyelései a fentieken kívül nincsenek.

1953. Senecio paludosus L. SK: Ásványráró: Szárcsás-tó, mocsárrét-töredéken [8171/3]; Bagamér, kubikgödrökben kialakult nedves, kavicsos felszíneken, pionír cserjés között [8171/3]; Győrladamér: Fekete-dűlő (Csikórét), magassásosban néhány tő [8271/2], a patkányosi gátőrháztól Ny-ra, feltöltődött kavicstó szélén és cserjésedő kékperjés réten [8271/2]; Győr: Holt-MosoniDuna-part, a Révfalui-csatorna torkolatánál, 1 példány [8271/4]; Kisbajcs: Szavai-csatorna szegélyében [8272/3].

1954. Senecio sarracenicus L. SK: Ásványráró: Kucsérok területén sokfelé, nádas-aranyvesszős állományok között és a területet felszabdaló levezetőcsatornák rézsűjén [8171/3], Alsó-Új-sziget [8171/3, 8171/1], Árva-sziget [8171/3], Töklevél-sziget [8171/4]; Dunakiliti: Fazekas-zátony, Márk-füzes, Alsó-Helena [8069/2]; Dunasziget: Külső-Jegenyés [8070/1], Dunaparti út mellett többfelé, Hosszúciglés-sziget [8070/1]; Győrzámoly: Nagy-Patkó-sziget [8171/4]; Lipót: a morotvató körüli mocsárrétek szélén, magaskórósokban [8170/2]; Rajka: Tározótér [8069/2], Jónás-sziget, Császár-liget [7969/3]. A szigetközi hullámtér mocsári magaskórós és füzes társulásaiban viszonylag elterjedt, ezen állományok valószínűleg az országban a legnagyobbak. Túlélő (nem virágzó) telepeivel nemes nyárasokban is gyakran találkozni.

1957. Senecio doria Nath. SK: Vámosszabadi: Szúnyogháza, a közúti híd mellett a Szavai-csatorna partján, több tucat tő [8271/2]. Aktuálisan ez az egy szigetközi előfordulása ismert. A POLGÁr (1941) által felsorolt három kisalföldi lelőhely közül kettőről bizonyosan kipusztult (Koroncó, Győr). RIEZING (2012a) a Kisalföld keleti feléről számos helyről jelzi, ahol magam is megfigyeltem.

1980. Cirsium eriophorum (L.) Scop. SK: Feketeerdő: a Mosoni-Duna-híd mellett, legelőn [8069/4]; Kunsziget: Tátai-erdő szélén, töltésalji üde gyepek- 
ben [8271/3]; Rajka: Felső-Osztály és Szigetek (a Tározótér területén belül), xeromezofil gyepekben [8069/2]. A Kisalföld jelentős területén hiányzik, csak az északnyugati részén szórványos.

2016. Hypochaeris maculata L. IKM: Győr: Kismegyer közelében, az Agroker telepével szemközti kis löszgyepfragmentumban, erdőssztyepp-növények társaságában [8371/2]. GTT: Győr: Győrszentiván: Ivánházi-homokpuszta, jó állapotú homokpusztagyepben, egy helyen kb. 10 tő [8272/4]. Megfigyeléseim szerint kötődik a zavartalan gyepekhez. PoLGÁR (1941) szerint Győrtől keletre szórványos, újabb kisalföldi jelzései a fentieken kívül nincsenek.

2042. Lactuca saligna L. CS: Győr: Rába töltésgyepjében a Haraszti-erdőnél, néhány tő [8371/3]. IKM: Töltéstava: Temető-dűlő (KG-SD) [8372/3]. A térségben kifejezetten ritka, korábban közölt két lelőhelyén (Pér, Győr, ScHMIDT 2010) újabban nem sikerült megfigyelni.

2059. Crepis pulchra L. IKM: Győrújbarát, vasúti sínek mellett az M1-es autópálya felüljárójánál [8372/3]. Vonalas létesítmények mentén terjedőben lévő honos növény, a Kisalföld területéről csak a közelmúltban mutatták ki (SCHMidt és Bauer 2005).

2137. Triglochin maritimum L. IKM: Győrújbarát: Csókatelki-árokban a győri településhatárhoz közel, néhány tucat tő [8371/4]; Töltéstava: Pozsgaitanyától Ny-ra, nedves réten, néhány tő [8372/3]. Polgár (1941) a szikes területekről még gyakorinak írja. SCHMIDT (2007) munkája nem erősíti meg előfordulását, ezt követően a tüzetes keresés során került elő.

2138. Triglochin palustre L. PDS: Győrszemere: a település délkeleti szélén, homokbányagödör sekély, nedves iszapos felszínein, néhány tucat példány [8471/3]. Az élőhely a bányamüvelés következtében 2013-ra megsemmisült. POLGÁr (1941) főként a szikes területrészről említi, ott újabb megfigyelései nincsenek, valószínüleg kipusztult.

2152. Ornithogalum $\times$ degenianum Polgár GTT: Győr: Nádorvárosi Köztemető parcellái között, laza, homokos talajon, 2-3 lokalitásban, összesen kb. 25 tő [8371/2]. PDS: Marcaltő: a község temetője mellett, árokszélen (KG-SD) [8570/3]. A Kisalföldről korábbi adata nem volt, a szomszédos Pannonhalmidombságból újabban találták (SCHмIDT 2015).

2158. Ornithogalum refractum Kit. in Willd. GTT: Győr: Nádorvárosi Köztemető parcellái között, laza, homokos talajon, sokfelé [8371/2]. PoLGÁR (1941) ugyaninnen közli, újabb kisalföldi adatai nem voltak.

2163. Scilla vindobonensis Speta GTT: Gönyü: Gönyüi-erdő Ny-i része, homokra ültetett cseres-fehér nyáras állományban, kisebb folton [8272/4]. Érdekes előfordulás egy kifejezetten száraz homoki erdőben. A Duna árterében ma is gyakori fajt a teraszvidékről mindeddig nem közölték, a közelben lévő Bőnyierdőben újabban KEVEY (2015) találta. 
2240. Leucojum aestivum L.SK: Győr: Sáráspuszta: Berekalja-dűlő, ligeterdőmaradványokban, több ponton, nem virágzó példányok [8271/4]; Győrzámoly: Fekete-dűlő (Csikórét), magassásos állományokban és nádasban, nagy tömegben [8271/2]. A Duna és a Mosoni-Duna ligeterdeiben (gyakran nemes nyárasokban is) elterjedt, sok helyen tömeges (adatai itt nem kerülnek felsorolásra), az ártéren kívüli területen a betöltődött folyóágak, kanyarulatok helyét jelzi.

2255. Iris arenaria Waldst. et Kit. GTT: Győr: Győrszentiván, az Erdőtelep és az Örök-föld között, az egyetlen épen megmaradt homoki sztyeppréten, kb. 20 töves állomány [8272/4]; Gönyü: Szilvás és Vérvirágos-rét, homokpusztagyepekben [8272/4]. Az új előfordulások a korábbi felsoroláshoz (SCHMIDT és BAUER 2005, SCHміDт 2010) jelentenek kiegészítést, pontosítást.

2265. Eriophorum angustifolium Honck. PDS: Győrszemere: Kúria-rét (SD-KG-PGy-WE) [8471/1]. A Győrszemere környéki nedves rétek növényzete egy korábbi tanulmányban már bemutatásra került (SCHMIDT 2011), akkor a gyapjúsás még nem került elő. Kis állományára Werner Ervin bukkant rá egy közös terepbejárás alkalmával.

2273. Juncus sphaerocarpus Nees. CS: Győr: Mákos-dülö, a vasút mellett [8371/2]. IKM: Győrújbarát: Pap-rét, az autópálya mellett [8372/3]. PDS: Kajárpéc: Pap-rét (a falutól Ny-ra [8571/2]; Tét: Tétszentkúttól ÉNy-ra, út menti árokban (KG-SD) [8570/2]. Belvizes szántókon, Juncus bufonius példányai között.

2282. Juncus subnodulosus Schrank PDS: Győrszemere: a település délkeleti szélén, homokbányató partján 3-4 erős csomó (2011) [8471/3], a Bakony-ér hídja melletti kiszáradó lápréten, pár tő (KG-SD) [8471/1]. Korábban a vizenyős mélyedések jellemző növénye volt (PoLGÁr 1913, 1941), mára e területek nagyfokú átalakulása miatt egészen megritkult.

2333. Poa nemoralis L. GTT: Győr: Győrszentiván, Haraszt-erdő, több ponton [8272/3], Szentiváni-erdő K-i részén, akácosban [8272/3]; Püspökerdő $[8271 / 4]$.

2346. Catabrosa aquatica (L.) P. Beauv. PDS: Győr: Ménfőtől nyugatra, a Koroncói úti temetőnél csordogáló kis érben, főként a frissen kikotort, nyílt részeken állományalkotó [8371/4]. POLGÁR (1941) régi adatának megerősítése, egyben a második recens megfigyelése a Kisalföldről.

2365. Glyceria notata Chevall. PDS: Győr: Ménfőtől nyugatra, a 83. számú főut elkerülő szakaszánál, kis ér partján (2013) [8371/4]. A termőhely a Catabrosa állományától kb. 500 méterre, északra található. Jelenleg az egyetlen biztos adata, de valószínúleg elterjedtebb a környéken.

2422. Helictotrichon adsurgens (Schur ex Simonk.) Conert GTT: Gönyüi-erdő, Vérvirágos-rét [8272/4]; Győr: Likócs, Segítőháztól D-re, fajgazdag homokpusztagyepben, kisebb állomány [8272/3], Szentiváni-erdő északi részén, (részben levágott) fenyvesek alatti zárványgyepekben elszórtan [8272/3]. 
2440. Hierochloë repens (Host) P. Beauv. SK: Győr: a város északi peremén, a Győrújfalura vezető kerékpárút melletti üde mezsgyén [8271/4], Mosoni-Duna jobb parti töltésén Pinnyédtől északra, több ponton [8271/4]. GTT: Győr: Ivánházihomokpuszta, kiszáradt buckaközi laposban, kékperjés foltokon [8372/4]; Sashegy: Tatai út mellett, útszéli mezsgyén az M1 felüljárótól Ny-ra [8372/1]. CS: Győr: a Rába töltésén többfelé megjelenik, mindkét oldalon [8371/2, 8371/3]; Katona-rét, Rába-dűlő [8371/1]. PDS: Mórichida, akácos szélén (KG-SD) [8470/4]. Üde (ritkábban szárazabb) gyepekben, főként útszéli zavart társulásokban szórványosan megjelenő faj, de a Rába töltésén akár gyakorinak is mondható.

2549. Schoenoplectus supinus (L.) Palla SK: Győr: Likócs, a városrész és a Mosoni-Duna között, a védtöltés melletti parlageredetű nedves rét belvizes mélyedésében [8272/3]. 2013 kora őszén került elő, amikor a rét egy része víz alatt volt, egy évvel később már nem jelent meg. Polgár (1941) Győr megyéből még számos lelőhelyről jelzi előfordulását, újabb publikált adata nem volt.

2585. Cladium mariscus (L.) Pohl CS: Győr: Újváros: Somos, kékperjés mélyedésben az 1-es út mellett, kisebb polikormon [8371/2]. Második recens adata a tágabb környékről.

2598. Carex divulsa Stokes subsp. divulsa GTT: Győr: Belváros, Teleki utca, az Ifjúsági ház mögött, vetett gyep között [8371/2]. Az elöfordulás bizonnyal behurcolás eredménye, környékbeli kisalföldi adata nincs (természetes élőhelyröl sem).

2633. Carex pseudocyperus L. SK: Rajka: a Tározótér É-i részén, a Jónásikavicstavak szegélyében [7969/3].

2641. Carex vesicaria L. SK: Győr: Sáráspuszta, Dunalapos-ér mocsári szegélynövényzetében, néhány méteres hosszon állományképző [8271/4]. Győr környéki folyópartok rétjein korábban gyakori volt (POLGÁR 1941), megszünésük, illetve eljellegtelenedésük miatt azonban jelentősen megritkult, fenti az egyetlen megerősített adata. RiEzING (2005) Ács és Komárom mellől jelzi.

2649. Carex hordeistichos Vill.IKM: Győr: KismegyertőlD-re a Malomszékidűlőben, belvizes szántó szélén, 3 erős tő [8371/4]. Időleges megtelepedését a földdarab megművelésének elmaradása segítette elő. A szántószegélyt a belvíz eltűnése után ismét beszántották. A C. secalina-hoz hasonló megjelenésű és élőhelyigényű faj, korábban Győr környékéről szórványosan jelezte PoLGÁR (1941), azóta újabb adatait nem publikálták a Kisalföldről.

2650. Carex secalina Wahlenb. GTT: Győr: Hecsepuszta, Dózsatagtól Nyra, belvizes szántón, 1 példány [8372/1]; Győrszentiván, Zsombékos, homokos dűlőúton 1 példány (SD-SzR) [8272/4]; Gönyü: Gulyajáró, homokbánya parti zónájában 1 tő [8272/4]. IKM: Győr: Kismegyertől D-re a Malomszéki-dűlőben, belvizes szántó szélén, tucatnyi példány [8371/4]. CS: Győr: Gyirmót, Széles-földek, építési terület nyílt belvizes felszínein többfelé, összesen több száz tő [8371/4], Gyirmót, a Határ utca és a 83. sz. föút között, belvizes szántón 
[8371/4]. PDS: Győrszemere: a település DK-i szélén, homokbányagödörben, kb. 15 tő [8471/3]. A növény korábban csak Nyúl mellől volt ismert (PoLGÁR 1941, Sснміdт 2011), az újabb megfigyelések szerint alkalmas élőhelyeken rendszeresen felbukkan Győr környékén is.

2653. Carex viridula Michx. PDS: Györszemere: a település DK-i szélén, homokbányagödörben [8471/3]; Koroncó: Zöldmajor, bányató melletti kubikgödör nyílt nedves felszínein, más sásfajokkal (C.panicea, C. flacca, C. tomentosa) együtt [8471/1].

2673. Epipactis helleborine (L.) Crantz SK: Győr: Sáráspuszta, Berekaljadűlő, nyárfasor alatt a Dunalapos-érnél [8271/4]; Kisbácsától K-re, kavicsbányató partján [8271/4].

2676. Cephalanthera damasonium (Mill.) Druce SK: Győrladamér: a patkányosi gátőrháztól Ny-ra, spontán puhafás állományban, néhány tő [8271/2]. PDS: Koroncó: a településtől DNy-ra, a Marcal mellett, bányató kubikgödrében, 1 példány [8471/1].

2677. Cephalanthera longifolia (L.) Fritsch IKM: Győrújbarát: Kákás-tó, nemes nyárasban 117 tő [8371/4]. PDS: Koroncó: a településtől DNy-ra, a Marcal mellett, bányató kubikgödrében, 1 sarjtelep (2014) [8471/1].

2680. Neottia nidus-avis (L.) Rich. GTT: Győr: Győrszentiván, Ivánházapusztától ÉK-re, homoki fehér nyárasokban, több ponton, kb. 35 tő [8272/4]; Gönyü: Gönyüi-erdő D-i részén, fehér nyárasban [8272/4].

2681. Listera ovata (L.) R. Br. CS: Győr: Bécsi úti nádas Ny-i csücskében, cserjésedő nedves gyepben 2 tő [8371/2]; Rábapatona: Vasút-alatti-dűlő, változó vízhatású kocsányos tölgyes ültetvényben és a vasút menti spontán nyíresben [8273/3]. Korábbi adata a Csornai-síkról: Győr, Rába-dűlő (SchмIDt 2010).

2693. Dactylorhiza incarnata (L.) Soó PDS: Győr: Gyirmót, a focipályától DNy-ra, jó állapotú réti csenkeszes mocsárréten (2013: 83 tő) [8371/4], továbbá a focipálya szomszédságában lévő magán horgásztavak körüli gyepekben is (SzGy-HL, 2013) [8371/4], Gyirmót és Ménfő között, a 83. sz. főút elkerülő szakaszával párhuzamosan futó árok gyomos szegélynövényzetében, a Széles-földek mellett (2013: 59 tő) [8371/4]. GTT: Győr: Szentiváni-erdő DNy-i részén, az új Audi-elkerüloút szomszédságában, egy mesterséges mélyedésben, 2 tő [8272/3]. A gyirmóti állományok a már korábban közölt lelőhelyhez (Gyirmót és Ménfő között, SCHMIDT és BAUER 2005) kapcsolódnak. Összességében stabil populációi élnek a térségben, amelyek közül néhányat a beépítés veszélye fenyeget (gyirmóti sporttelep bővítése, horgásztó körüli gyepek nyírása).

2703. Neotinea ustulata (L.) R. M. Bateman, Pridgeon et M. W. Chase SK: Dunakiliti: a Zátonyi-Duna-ág legfelső szakaszának egy kanyarulata által közrefogott kis homokpusztagyep-töredékén, 8 tő [SD-FZ) [8069/2]. A Szigeti-Dunából kiágazó Zátonyi-Duna-ágnak a Jánosi-erdőtől ÉNy-ra eső szakasza a Tározótér gát- 
jának és aljzatának kialakításakor (az 1980-as évek első felében) holt mederré vált, feltöltődése napjainkban folyamatos. Éles kanyarulata egy kis területủ ármentes hordalékpadot fog közre, melyen nyílt homokpusztagyep alakult ki. Állományképző füfaj a Bromus erectus, Koeleria cristata, gyakori a Carex liparicarpos, C. flacca, Euphorbia segueriana, Teucrium chamaedrys, Linum austriacum, Linaria genistifolia.

2705. Orchis militaris L. SK: Dunakiliti: a Szigeti-Duna és a Tározótér gátja között többfelé, kb. 150-200 tő [8069/2]; Rajka: Császár-liget [7969/3]. PDS: Koroncó: a településtől DNy-ra, a Marcal mellett, bányató kubikgödrében, 1 példány, valamint a bányatótól $\mathrm{D}$-re az országút mellett, anyagnyerő kazettákban, tucatnyi tő [8471/1]. Sokféle élőhelytípusban él: nedves pionír gyepekben, mezofil réten, nyers kavicson felverődött nyarasokban, spontán puhafás állományokban.

2709. Anacamptis palustris Jacq. PDS: Győr: Gyirmót, a focipályától DNyra, jó állapotú réti csenkeszes mocsárréten (2013: 223 tő) [8371/4], továbbá a focipálya szomszédságában lévő magán horgásztavak körüli gyepekben is (SzGy-HL) [8371/4]. A lelőhelyek közelében (a 83. sz. foút túloldalán) található a SCHмIDT (2010) által jelzett előfordulás.

2714. Ophrys apifera Huds. GTT: Győr: Győrszentiván, Szentiváni-erdő DNy-i része [8272/4]. Egy évvel a faj 2010 júliusi megtalálását (SCHMIDT 2011) követően az első (azóta megszűnt, beépített) lelőhelytől 1 km-re keletre, a Szentivánierdő nyugati peremén, az új elkerülöút (Audi Hungária út) közvetlen közelében, egy középkorú erdeifenyő-csoport alatt találta meg Király Gergely egy kisebb populációját. A várható beépítés miatt az állományt a Fertő-Hanság Nemzeti Park munkatársai áttelepítették Nagyszentjánosra. Az áttelepített állománytól kb. 100 méterre, 2013. június 10-én újabb populáció került elő egy erdeifenyővel beültetett mélyedésben. A virágzó tövek száma itt 2013-ban $13 \mathrm{db}$, 2014-ben $102 \mathrm{db}$ volt.

2715. Ophrys sphegodes Mill. GTT: Gönyű: Gönyüi-erdő, Vérvirágos-rét, 2 virágzó példány zárt homokpusztagyepben (SD-SzR-TV) [8272/4]. Ezen a réten található a Daphne cneorum subsp. cneorum egyedüli kisalföldi termőhelye, gyakori továbbá a Stipa pennata, Carex humilis, Adonis vernalis, Orchis morio, Iris arenaria, Pulsatilla nigricans.

\section{Adventív fajok}

144. Humulus scandens (Lour.) Merr. CS: Győr: a Rába bal partjának fátyoltársulásában, egyelöre egy ponton, a Marcal torkolata felett [8371/3]. A Rába középső szakaszáról már korábbról megfigyelték terjedését (BALOGH és DANCZA 2006, 2012), az alsó szakaszról ez az első jelzése.

210. Chenopodium aristatum L. GTT: Győrszentiván-Kertváros, útszéli homoki gyomtársulásokban és kertekben, nyílt homokfelszíneken [8272/3], Győrszentiván: Új temetőtől D-re, nyílt homokfelszíneken [8272/3]. A Győrtől 
keletre lévő homokpusztákról először Pinke és PÁl (2001), majd Schmidt és BAUER (2005) jelezte. Újabb felbukkanásai ellenére terjedése nem számottevő, csekély jelenléte a nyílt homoki gyomtársulások szegényes fajkészletét színesíti.

211. Chenopodium ambrosioides L. CS: Ikrény: Holt-Rába torkolatánál a Rába árterében, mocsári gyomtársulásban [8371/3]. SK: Dunakiliti: Fazekas-zátony és a Duna-parti kavicsos út mentén [8070/1]; Dunasziget: Duna-parti kavicsos út mentén az 1840. és 1833. fkm. között [8070/1; 8070/3]; Ásványráró: Madarász-sziget [8171/4]; Vének: Kolera-sziget [8272/4]. Vízparti friss iszapon kialakult egyéves fajközösségekben fordul elő, hasonló élőhelyről közli PoLGÁR $(1936,1941)$ is.

267. Amaranthus crispus (Lesp. et Thévenau) N. Terrac SK: Hédervár: a falu keleti felén, a Fö út mellett, ház mögötti gyomtársulásban [8170/4]; Mecsér: Kossuth Lajos utca, járdarepedésben [8270/2].

272. Oxybaphus nyctagineus (Michx.) Sweet CS: Győr: Újlaki utcai vasúti átjáró, kerítés tövén [8371/2]. A 2000-es évek elején megfigyelt állomány, mely az utóbbi évek intenzívebb gyomirtása miatt már csak néhány nem virágzó egyedet számlál. Vasutak mentén terjedő gyom, a Kisalföldről RIEZING (2005) és KIRÁLY et al. (2009) tudósít megjelenéséről, mindkét helyen jelenleg is tenyészik.

274. Phytolacca esculenta van Houtte SK: Győr: Sáráspuszta: Berekaljadűlő, ligeterdö-maradványban [8271/4]. Települési környezetben rendszeresen, de általában kis példányszámban fellép, különösen udvarokon, falak mentén, építési területeken. BALOGH (2005) a Kisalföldről már számos lelőhelyről ismerteti. [Helyreigazításként közlöm, hogy a korábbi cikkben (SснміDT 2010) említett Koroncó-Tét környéki tömeges előfordulás elírás, valójában a Ph. americana L.-ra vonatkozik.]

656. Ribes aureum Pursh. CS: Győr: M1-es autópálya Rába-hídjának rézsüjén [8371/2], Gyirmót: Szegle, homoki akácos szélén [8371/3]. SK: Györ: Szitásdomb, telepített fenyvesben néhány bokor [8271/4]. PDS: Koroncó: Zöldmajor-tól K-re, akácos szélén [8471/1]. Újabban többfelé telepítik, az ültetések helyén stabil, lassan terjeszkedő telepet hoz létre, de a Duna-Tisza közihez hasonló nagymértékű elvadulásáról még nem beszélhetünk. A térségből az első konkrét adatai.

660. Ribes rubrum L. GTT: Győr: Győrszentiván-Kishegy, Haraszt-erdő Ny-i részén, telepített fenyvesben [8272/3]. SK: Győr: Püspökerdő [8271/4], Sáráspuszta: Berekalja-dűlő, ligeterdő-maradványokban elterjedt [8271/4]. PDS: Tét: Tétszentkúttól ÉNy-ra, út menti árokban (KG-SD) [8570/2]. Haraszt-erdei előfordulását RIEZING $(2011,2012 a)$ is említi.

671. Rubusphoenicolasius Maxim. PDS: Felpéc: Sísek-domb, telepített erdeifenyvesekben, több $10 \mathrm{~m}^{2}$-es állományok [8471/3, 8471/4]. Új a Kisalföldre. A közeli Pannonhalmi-dombságról SCHMIDT (2015) publikálja adatait.

661. Platanus $\times$ hybrida Brot. CS: Győr: Belváros, Radósziget parti kövezésének repedéseiben spontán kelt többéves egyedek [8371/2]. 
858. Robinia viscosa Vent. GTT: Győr: Győrszentiván, Malom utca végén, az M19-es út mezsgyéjén, kivadult példányok [8272/3]; Kismegyer: Kismegyeri utca, útszéli árokban kivadulva [8272/4]. IKM: Győr: Kert utca elején, a lebontott dobozgyár helyén, építési törmeléken számos fiatal egyed [8371/2]. Gyakran ültetett díszfa, mely gyökérsarjról könnyen kivadul. Viselkedése és terjedési képessége alapján a jövőben potenciális invádorként lehet vele számolni. Új a Kisalföldre.

1017. Geranium sibiricum L. GTT: Győr: Győrszentiván-Újmajortól DKre, erdeifenyvesben vezető homokos erdei út száraz szegélytársulásában, néhány méteres szakaszon [8272/3]. SK: Ásványráró: Alsó-Új-sziget, a Dunához közel, kocsiút közének taposott üde gyepjében, néhány tő [8171/1], az Árvai-zárás közelében, nyílt kavicsfelszínen [8171/3] (A hullámtérről az első adatai), Zsejkepuszta, a kerékpárút melletti mezsgyén [8271/1]; Győr: Rónay Jácint utca, járdaszegélyen 2-3 tő (2013) [8371/2]; Győrzámoly: kerékpárút szegélyén a Zámolyi-csatorna közelében [8271/3]; Mecsér: Zsejkei-erdő, útszegélyen [8170/4]. A Győr-Tataiteraszvidéken eddig nem találták, minden bizonnyal új megtelepedés.

1067. Euphorbia taurinensis All. GTT: Győr: Győrszentiván: Ivánháza és az Erdeitanya között, levágott fenyves helyén kialakult homoki gyomtársulásban, néhány száz tő [8272/4]. A térségben szórványos faj, korábbi adatai Bőny, Bana, Győrszentiván homokos élőhelyeiről származnak (Polgár 1941, SCHMIDT és BAUER 2005).

1091. Impatiens glandulifera Royle SK: Győr: Sáráspuszta: Berekaljadűlö, ligeterdő-maradványokban, több ponton [8271/4]. A Felső-Szigetközben az Öreg-Duna árterében a legtöbb helyen tömeges faj (különösen nemes nyárasokban), de DK felé némileg megritkul. Korábbigyőrijelzését (Püspökerdő, SCHMidT és BAUER 2005) követően a Mosoni-Duna mellöl viszont nem volt újabb megfigyelése.

1092. Impatiens balfourii Hook. GTT: Győr: Adyváros, lakótelepi ágyásokból számos helyen kivadulva, pl. Szigethy Attila út [8371/2]. A környéken egyelőre csak átmeneti kivadulásai ismertek, a közeli Pannonhalmi-dombságon több helyütt meghonosodott (SCHMIDT és LENGYEL 2008).

---. Viola sororia Willd. GTT: Győr: Belvárosi előkertekben, gyepekben kivadulva és meghonosodva, pl. Kiss János utca [8371/2].

1589. Buddleja davidii Franch. SK: Ásványráró: Alsó-Új-sziget [8171/1; 8171/3], valamint a Duna-parti út mellett Lipót és Ásványráró között kavicshalmokon [8170/2]. Szigetközi előfordulását BALOGH (2003) jelezte első ízben, az eltelt szük másfél évtizedben állományai nem nőttek drasztikusan. IKM: Győr: Pápai út szegélyén a Tesco-val szemben, útszéli köves helyen, 3-4 fiatal példány [8371/2]. CS: Győr: Újváros, a Termálfürdőnél, fal tövén, kisebb egyed [8371/2]. Mindkét győri előfordulás új, a közelben élő ültetett egyedek magszórásából származik. 
1649. Veronica peregrina L. SK: Győr: Szúnyog-sziget, a Mosoni-Duna iszapos partján [8371/2]. A Mosoni-Duna-partról először SCHMIDT és BAUER (2005) Halászi mellől közli.

---. Campanula poscharskyana Degen GTT: Győr: Belváros, a Babits Mihály utca téglakerítésein elvadulva [8371/2]. Hazai elvadulásáról elsőként KIRÁLY et al. (2009) számol be.

2463. Alopecurus myosuroides L. GTT: Győr: Győrszentiván: Szentivánierdő, erdeifenyves kivágása után gyepesített területeken, a vetett gyep között [8272/3], Ivánháza és az Erdeitanya között, kivágott fenyves helyére vetett gyepben, nagy tömegben [8272/4]. PDS: Győr: a város déli peremén, a GyirmótiBerettyó mellett, a pápai vasútnál, parlagokon, nagy tömegben [8471/2]. Erősen terjedőben lévő gyomnövény, fenti lelőhelyein az utóbbi 5-6 évben jelent meg $s$ vált egyre gyakoribbá. Vetett gyepben való tömeges fellépése (Szentiváni-erdő, Ivánháza) vetőmaggal való behurcolás eredménye. A Rábaköz kötött talaján már sokfelé tömeges faj, pl. a Koroncó és Rábapatona közötti szántókon. Király G. szerint (ex litt.) a Kisalföldön mintegy 15 éve indult meg tömeges elterjedése.

2497. Eleusine indica (L.) Gaertn. IKM: Győr: Nádorvárosi Köztemető déli bejárata mellett a Szentlélek templomnál, járdarepedésekben, tucatnyi tő [8371/2]. PolgÁr $(1918,1933)$ szintén Győr belterületén, gyárak mellett figyelte meg néhány példányát. Újabban egyre többfelé bukkan fel az országban, de más kisalföldi jelzése ez idáig nem volt, 2014 őszén célzott keresés eredményeként került elő.

---. Panicum riparium H. Scholz PDS: Koroncó: Bábota-domb mellett, legelőn, feltúrt helyen [8371/3]. GTT: Győr: M1-es autópálya győrszentiváni lehajtója mellett, útszélen [8372/2], Likócstól ÉNy-ra, törmeléklerakón, több tucat egyed [8272/3]. A közelmúltban leírt, majd hazánkban is kimutatott faj (KIRÁLY et al. 2009), első jelzése a Győr-Tatai-teraszvidékről.

2517. Cenchrus incertus M. A. Curtis GTT: Győr: a vasúti föpályaudvaron, valamint ettől keletre a Teherpályaudvarig több ponton, vágányok közötti kőzúzalékon, összesen kb. 30 tő [8371/2], Győr-Gyárváros vasúti megállótól 1 km-re keletre, a vasúti őrháznál, 2 példány [8372/1], GySEV-teherpályaudvar, néhány tő, Tragus racemosus, Digitaria ciliaris társaságában [8371/2]. Vasutak mentén terjedőben lévő özöngyom, fentiek az első kisalföldi adatait jelentik.

\section{Köszönetnyilvánítás}

Köszönet illeti Király Gergelyt a nehezebben határozható Panicum riparium és Rubus montanus azonosításában nyújtott segítségéért, saját adatai felhasználásának lehetőségéért és a cikkhez füzött hasznos észrevételeiért. Köszönöm továbbá valamennyi kollégámnak a közös terepbejárások során nyújtott segítséget. 


\section{Irodalomjegyzék}

BAlogh L. 2003: Buddleja davidii Franch. a Szigetközben. Kitaibelia 8(1): 185-186.

BALOGH L. 2005: Phytolacca esculenta Van Houtte Magyarországon. Flora Pannonica 3: 135-161.

BAlogh L., Dancza I. 2006: Japán komló (Humulus japonicus). In: Botta-Dukát Z., MıнÁly B. (szerk.) Biológiai inváziók Magyarországon. Özönnövények II. A KvVM Természetvédelmi Hivatalának Tanulmánykötetei 10., pp. 337-360.

BALOGH L., DANCZa I. 2012: Japán komló (Humulus japonicus). In: CsiszáR Á. (szerk.) Inváziós növényfajok Magyarországon. Nyugat-magyarországi Egyetem Kiadó, Sopron, pp. 101-104.

BARINA Z. 2003: Adatok az esztergomi Duna-ártér flórájához. Kitaibelia 8: 55-63.

DövÉNYI Z. (szerk.) 2010: Magyarország kistájainak katasztere. MTA Földrajztudományi Kutatóintézet, Budapest, $876 \mathrm{pp}$.

EвENHÖch F. 1876: A megye viránya. In: FeHÉR I. (szerk.) Győr megye és város egyetemes leírása. Franklin Társulat, Budapest, pp. 97-132.

Feichtinger S. 1899: Esztergom megye és környékének flórája. Esztergom-Vidéki Régészeti és Történelmi Társaság kiadványa, Esztergom, 456 pp.

GÁYER Gy. 1916: Komárommegye virágos növényeiről. Magyar Botanikai Lapok 15: 37-54.

KeVEy B. 1998: A Szigetköz erdeinek szukcessziós viszonyai. Kitaibelia 3: 47-63.

KEVEY B. 2015: Adatok Magyarország flórájának és vegetációjának ismeretéhez X. Botanikai Közlemények 102: 39-60. http://doi.dx.org/10.17716/BotKozlem.2015.102.1-2.39

Kevey B., Alexay Z. 1992: Adatok a Szigetköz flórájához. Acta Ovariensis 34: 29-37.

Kevey B., AleXay Z. 1994: A Szigetköz dárdás nádtippanos-füzlápjai (Calamagrostio-Salicetum cinereae). Acta Agronomica Óváriensis 36: 7-22.

Kevey B., Alexay Z. 1996a: A Szigetköz tőzegpáfrányos-égerlápjai (Thelypteridi-Alnetum). Széchenyi István Főiskola, Györ. Tudományos Közlemények 7: 1-24.

Kevey B., Alexay Z. 1996b: A Szigetköz mocsári sásos-égerlápjai (Carici acutiformis-Alnetum). Természetvédelmi Közlemények 3-4: 81-96.

Kevey B., Czimber Gy. 1982: Az Allium ursinum növényföldrajzi szerepe a Szigetközben. Agrártudományi Egyetem, Keszthely. A Mosonmagyaróvári Mezőgazdaságtudományi Kar Közleményei 24: 261-297.

Király G. (szerk.) 2007: Vörös Lista. A magyarországi edényes flóra veszélyeztetett fajai. Saját kiadás, Sopron, $73 \mathrm{pp}$.

KIRÁLY G. (szerk.) 2009: Új magyar füvészkönyv. Magyarország hajtásos növényei. Határozókulcsok. Aggteleki Nemzeti Park Igazgatóság, Jósvafö, 616 pp.

Király G., BARANYAi-NAGy A., Kerekes Sz., Király A., Korda M. 2009: Kiegészítések a magyar adventív-flóra ismeretéhez IV. Flora Pannonica 7: 3-31.

KirÁly G., HoRVÁth F. 2000: Magyarország flórájának térképezése: lehetőségek a térképezés hálórendszerének megválasztására. Kitaibelia 5: 357-368.

KiRÁLY G., KirÁLY A. 1999: Adatok és kiegészítések a magyar flóra ismeretéhez. Kitaibelia 4(2): $229-246$.

KirÁLY G., KirÁLY A. 2006: Adatok és kiegészítések a magyar flóra ismeretéhez II. Kitaibelia 10: $88-103$.

KirÁLY G., KirÁLY A. 2009: Adatok a Salix elaeagnos Scop. magyarországi elöfordulásához. Flora Pannonica 7: 79.

KirÁly G., TAKÁcs G., KirÁly A. 2015: Adatok a Kisalföld flórájához és növényföldrajzához. Kitaibelia 20(2): (in press).

LÁJER K. 1997: A Marcal-medence déli részének lápi és lápréti növénytársulásai. Kitaibelia 2(2): 281-289.

LÁJER K. 1998: Bevezetés a magyarországi lápok vegetáció-ökológiájába. Tilia 6: 84-238. 
NÉMETH Cs. 2008: Adatok a Súri-Bakonyalja, a Bakony és a Vértes mohaflórájához. Flora Pannonica 6: 79-87.

ORBÁN S., VAJDA L. 1983: Magyarország mohaflórájának kézikönyve. Akadémiai Kiadó, Budapest, $518 \mathrm{pp}$.

Papp B., ErZberger P., Ódor P., Hock Zs., Szövényi P., SZurdoki E., Tóth Z. 2010: Updated checklist and red list of Hungarian bryophytes. Studia botanica hungarica 41:31-59.

PINKe Gy. 1998: Adatok a Mosoni-sík és a Szigetköz gyomflórájának ismeretéhez. Kitaibelia 3(1): $105-108$.

PINKe Gy. 2000: Extenzív szántók gyomcönológiai vizsgálata a Kisalföldön. Doktori (PhD) értekezés Tézisei, Pécs-Mosonmagyaróvár, 10 pp.

Pinke Gy., PÁL R. 2001: Adatok a Kisalföld gyomflórájának ismeretéhez. Kitaibelia 6: 381-400.

POLGÁR S. 1913: Győr megye növényföldrajza és edényes növényeinek felsorolása. Magyar Botanikai Lapok 11: 308-338.

Polgár S. 1933: Neue Beiträge zur Adventivflora von Győr (Westungarn) II. Magyar Botanikai Lapok 17: 27-41.

Polgár S. 1936: Újabb adatok a magyar flórához. Botanikai Közlemények 33(1-6): 222.

POLGÁR S. 1941: Győrmegye flórája. Flora Comitatus Jaurinensis. Botanikai Közlemények 38: 201-352.

RIEZING N. 2005a: Adatok a Gönyü-Neszmély közötti Duna-szakasz flórájához és vegetációjához. Botanikai Közlemények 92: 57-67.

Riezing N. 2005b: Polystichum aculeatum (L.) Roth a Kisalföldön. Kitaibelia 10(1): 198.

RiEzing N. 2011: A Györ-Tatai Kisalföld erdei: tájtörténet és vegetáció. Tájökológiai Lapok 9: 209-217.

Riezing N. 2012a: Adatok a Győr-Tatai Kisalföld flórájához és vegetációjához. Botanikai Közlemények 99: 81-102.

RIEZING N. 2012b: Maradványerdők a kisalföldi peremvidék erdőssztyep zónájában. Tájökológiai Lapok 10: 371-384.

SCHмidT D. 2007: A Győr környéki szikesek növényzete. Flora Pannonica 5: 95-104.

SснміDт D. 2010: Adatok a Kisalföld flórájának ismeretéhez II. Botanikai Közlemények 97: 79-96.

SснміDт D. 2011: Kiegészítések a Kisalföld flórájához és vegetációjához. Kitaibelia 15: 109-117.

SснміDт D. 2015: Újabb adatok a Pannonhalmi-dombság flórájához. Kitaibelia 20(1): 67-73. http://doi.dx.org/10.17542/kit.20.67

SCHмidt D., BAUER N. 2005: Adatok a Kisalföld flórájának ismeretéhez I. Botanikai Közlemények 92(1-2): 43-56.

Schmidt D., Lengyel A. 2008: Adatok a Pannonhalmi-dombság flórájának ismeretéhez. Flora Pannonica 6: 25-59.

Sımon T. 1962: A Kisalföld természetes növénytakarója. Földrajzi Közlemények 86(2): 183-193.

Soó R. 1964-1980: A magyar flóra és vegetáció rendszertani és növényföldrajzi kézikönyve I-VI. Akadémiai Kiadó, Budapest.

SzÜcs P. 2007a: A Campylopus introflexus (Hedw.) Brid. új hazai előfordulása az Ácsi-erdőben. Kitaibelia 12(1): 145.

SzŰcs P. 2007b: Dunaalmás és Neszmély környékének mohaflórája. Botanikai Közlemények 94(1-2): 91-115.

WERNER E. 1990: A Felső-Szigetköz néhány botanikai értéke. A Mosonmagyaróvári Kossuth Lajos Gimnázium Évkönyve, 1989-1990: 20-29.

WierzBiCKI A. P. P. 1824: Flora Mosoniensis. Exhibens plantas phanerogamas et filices Comitatus Mosoniensis confiniumque sponte crescentes. Mscr., Deposited in the Botanical Department of the Hungarian Natural History Museum, Budapest.

ZóLYomi B. 1937: A Szigetköz növénytani kutatásának eredményei. Botanikai Közlemények 34: 169-192. 


\title{
Data to the flora of Kisalföld III
}

\author{
D. SCHMIDT \\ University of West Hungary, College of Wood Sciences, Institute of Botany, \\ Bajcsy-Zs. út 4, Sopron, H-9400; Hungary; david.schmidt@emk.nyme.hu
}

Accepted: 30 September 2015

Key words: habitat change, Győr, Kisalföld, rare species, urban flora

This study summarizes the most important results of floristical surveys between 2010 and 2015. The aim of this study was to explore the vegetation of the Northern Kisalföld, and publish the most valuable floristical data there. These data are evaluated according to their importance, phytogeographical and nature conservation values. The first part of the enumeration contains data for 3 bryophyte species and 115 native vascular plant species, the second part lists 23 adventive plants. Significant results include the detection of occurrence of Ornithogalum $\times$ degenianum and Rubus montanus, which are new for the flora of Kisalföld, and new localities for Cnidium dubium, Gentiana pneumonanthe, Samolus valerandi and Ophrys sphegodes, which are important from a nature conservation viewpoint. Additional valuable results are new data of Dryopteris dilatata, Ophrys apifera and Ornithogalum refractum, each being rare in the Kisalföld region. Small stands of Orobanche gracilis, Senecio doria and Veronica teucrium in the Szigetköz region represent an important discovery. Among adventive elements, Cenchrus incertus and Rubus phoenicolasius are new for the Kisalföld, while Eleusine indica were rediscovered after its first report in 1932. 